\title{
BMJ Open Migration pattern and mortality of ethnic German migrants from the former Soviet Union: a cohort study in Germany
}

Simone Kaucher, ${ }^{1}$ Andreas Deckert, ${ }^{1}$ Heiko Becher, ${ }^{1,2}$ Volker Winkler ${ }^{1}$

To cite: Kaucher S, Deckert A, Becher $\mathrm{H}$, et al. Migration pattern and mortality of ethnic German migrants from the former Soviet Union: a cohort study in Germany. BMJ Open 2017;7:e019213. doi:10.1136/ bmjopen-2017-019213

- Prepublication history and additional material for this paper are available online. To view these files, please visit the journal online (http://dx.doi. org/10.1136/bmjopen-2017019213).

Received 17 August 2017 Revised 3 November 2017 Accepted 6 November 2017

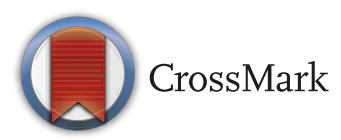

${ }^{1}$ Unit of Epidemiology and Biostatistics, Institute of Public Health, University Hospital Heidelberg, Heidelberg, Germany ${ }^{2}$ Institute for Medical Biometry and Epidemiology, University Medical Center HamburgEppendorf, Hamburg, Germany

Correspondence to PD Dr Volker Winkler; v.winkler@uni-heidelberg.de

\section{ABSTRACT}

Objective We aimed to investigate all-cause and causespecific mortality among ethnic German migrants from the former Soviet Union by different immigration periods to describe associations with migration pattern and mortality.

Design We used pooled data from three retrospective cohort studies in Germany.

Participants Ethnic German migrants from the former Soviet Union (called resettlers), who immigrated to Germany since 1990 to the federal states North RhineWestphalia and Saarland and to the region of Augsburg $(n=59390)$.

Outcome All-cause and cause-specific mortality among resettlers in comparison to the general German population, separated by immigration period.

Methods Immigration periods were defined following legislative changes in German immigration policy (19901992, 1993-1995, 1996+). Resettlers' characteristics were described accordingly. To investigate mortality differences by immigration period, we calculated agestandardised mortality rates (ASRs) and standardised mortality ratios (SMRs) of resettlers in comparison to the general German population. Additionally, we modelled sexspecific ASRs with Poisson regression, using age, year and immigration period as independent variables.

Results The composition of resettlers differed by immigration period. Since 1993, the percentage of resettlers from the Russian Federation and non-German spouses increased. Higher all-cause mortality was found among resettlers who immigrated in 1996 and after (ASR $628.1,95 \% \mathrm{Cl} 595.3$ to 660.8$)$, compared with resettlers who immigrated before 1993 (ASR 561.8, 95\% Cl 537.2 to 586.4). SMR analysis showed higher all-cause mortality among resettler men from the last immigration period compared with German men (SMR 1.11, 95\% Cl 1.04 to 1.19), whereas resettlers who immigrated earlier showed lower all-cause mortality. Results from Poisson regression, adjusted for age and year, corroborated those findings.

Conclusions Mortality differences by immigration period suggest different risk-factor patterns and possibly deteriorated integration opportunities. Health policy should guard the consequences of immigration law alterations with respect to changing compositions of migrant groups and their health status.

\section{Strengths and limitations of this study}

- This study includes a large number of resettlers living in Germany and a mortality follow-up of 20 years, thus we were able to investigate differences of resettlers' mortality based on their migration pattern for the first time.

- Since resettlers are distributed randomly to their place of residence, we assume that our results are generalisable to resettlers living in other regions of Germany.

- Data on risk-factor patterns and integration process were not available since registry data were used.

- Information on statutory basis was only available for a subgroup of the cohort.

\section{INTRODUCTION}

In the 18th and 19th centuries, Germans emigrated to the Russian empire. At the beginning, they were privileged compared with the Russian population, but since about World War I, they became persecuted and suffered increasing discrimination. In the 1930s and thereafter, many ethnic Germans were deported to specific regions within the former Soviet Union (FSU), most of them to Kazakhstan and Siberia. There, they were forced to work in agriculture and were not allowed to return to their places of residence from pre-war years. ${ }^{1}$ Since 1953 , ethnic Germans and their families, including non-German spouses and their children (descendants), were invited to return to Germany based on the Federal Expellee Law (in German: Bundesvertriebenengesetz), resulting in immigration waves from Poland and Romania, for instance. Yet, in the countries of the FSU, migration was hindered by strict emigration regulations. However, after the collapse of the Soviet Union, a massive emigration of ethnic Germans and their families, called resettlers (in German: (Spät-) Aussiedler), took place. ${ }^{2}$ By law, on arrival, 

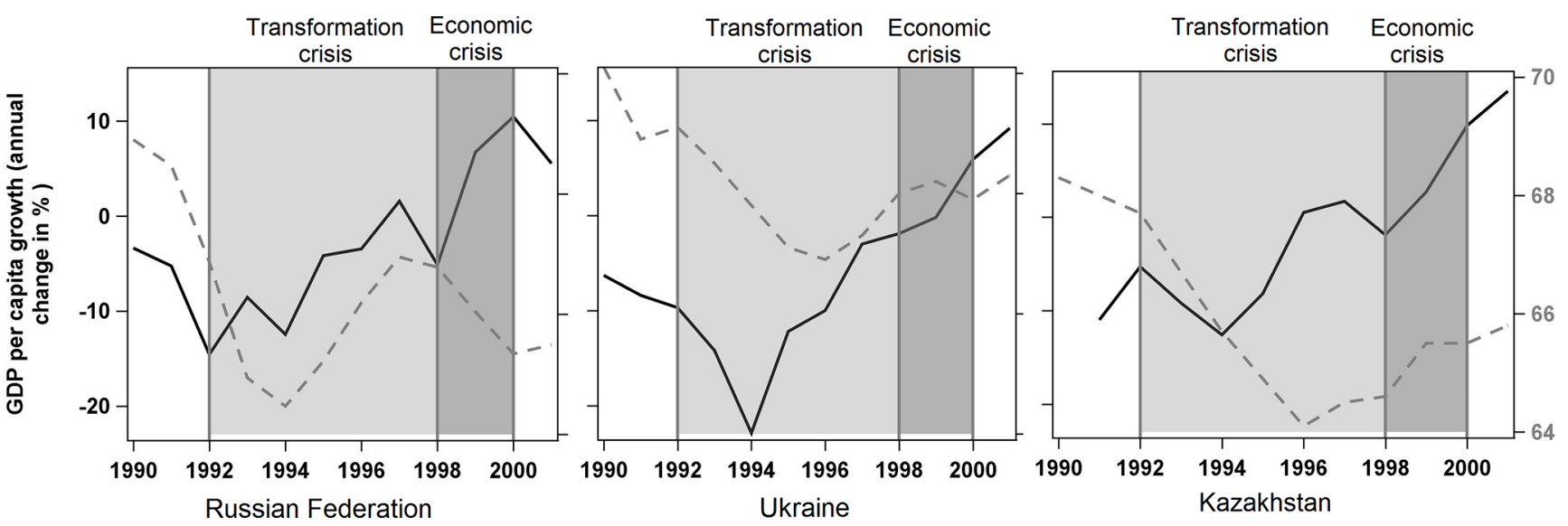

Figure 1 Annual change of gross domestic product per capita growth in per cent and life expectancy at birth in the 1990s in the Russian Federation, Ukraine and Kazakhstan. ${ }^{10}$

resettlers are granted full German citizenship. ${ }^{3}$ By 1989 , the Institute of German Economy assumed that the integration of resettlers will be easy due to very good conditions for integration. ${ }^{4}$ Many of the older resettlers spoke German and were familiar with the German culture and traditions. ${ }^{5}$ Between 1990 and 2005, more than 2 million resettlers from the FSU migrated to Germany. ${ }^{6}$

After the fall of the Iron Curtain, the so-called transformation crisis arose and consequently, the countries of the FSU had to handle multiple political and economic challenges. For instance, life expectancy and GDP dropped sharply in the Russian Federation, ${ }^{7}$ but also in the Ukraine and in Kazakhstan ${ }^{89}$ (see figure 1). ${ }^{10}$

Due to the high number of immigrating resettlers with a peak of 213000 from the FSU in $1994,{ }^{6}$ the German government began to further regulate the flow of immigration with the help of various legislative changes. ${ }^{2}$ In 1989, the law of residence assignment (in German: Wohnortzuweisungsgesetz) was introduced. To avoid agglomerations, incoming resettlers were allocated to their first place of residence based on regional population density and economic performance (in German: Königsteiner Schlüssel), where they had to live for at least 2 years (since 2005 3years). ${ }^{11}$ Besides this, there were hardly any restrictions on admission for resettlers. In 1993, the German government issued the Adjustment of Laws on the Effects of War (in German: Kriegsfolgenbereinigungsgesetz). Due to prior criticism about family separations of resettlers, the involvement of immigrating family members was facilitated. Henceforth, resettlers could immigrate with other descendants (eg, daughter or son-in-law, stepson or stepdaughter). Before 1993, families may not have immigrated because they may have been allocated to different places of residence. Nevertheless, annually a maximum number of about 220000 resettlers including family members were allowed to immigrate. From 1996 onwards, laws were again changed and a proof of German language skills was prerequisite for immigration. Only the principal applicant of the family had to be able to conduct a simple conversation in German. If the applicant passed the test, the whole family was allowed to immigrate. ${ }^{2}$ Furthermore, resettlers were penalised by cutting social security and unemployment benefits if they left the assigned place of residence within the first 2years. ${ }^{11}$ Since 2005, incoming resettlers and all family members have to prove German language skills before immigration. ${ }^{2}$

As a consequence of the described developments in the FSU countries as well as the legislative changes in Germany, the composition of resettlers changed. In course of the years, the number of immigrating resettlers decreased and an alteration with regard to the country of origin was observed. In addition, the number of incoming resettlers decreased since the majority already immigrated in the years before. The proportion of resettlers from the Russian Federation increased from $28.6 \%$ in 1993 to $45 \%$ in 2001 (see figure 2). ${ }^{3612}$ In addition, the proportion of couples increased where one of the partners had no German background. ${ }^{11}$ Furthermore, qualitative research

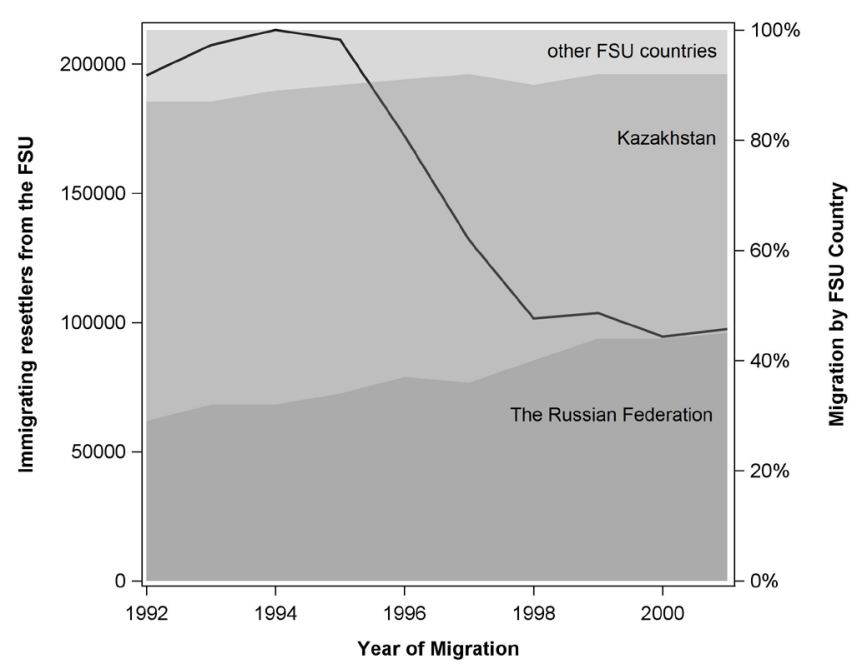

Figure 2 Total amount of immigrating former Soviet Union (FSU) resettlers by year (left axis) and composition of countries of origin from immigrating resettlers from the FSU by year (in \%, right axis). ${ }^{6}$ 
found decreasing German language skills ${ }^{2}{ }^{11}$ since the composition of immigrating resettlers changed and the language courses were scaled back during the 1990s. ${ }^{12}{ }^{13}$ Increasing integration problems among resettlers were seen over time since the acceptance of the society decreased, as well as the chances in the labour market, and the government spent less money for language courses and social benefits. ${ }^{211} 14$

Previous studies investigating the health situation of resettlers in Germany found a lower all-cause mortality among resettlers in three regionally different cohorts compared with the general German population, mainly driven by lower cardiovascular disease (CVD) mortality, ${ }^{15} 16$ whereas cancer incidence and mortality showed cancer-specific differences. ${ }^{17}{ }^{18}$ Data from a small case-control study suggest that those differences may be due to lifestyle factors. ${ }^{19}$ Since resettlers used to live within encapsulated communities for centuries almost until World War II, a different genetic pattern to those of the German and the Russian population might be possible. Further analyses from the conducted studies found higher external mortality among resettlers compared with the Germans. ${ }^{20} 21$ Except of Deckert et al, ${ }^{20}{ }^{22}$ previous analyses investigated resettlers as a homogeneous group. Deckert et al found differences in mortality with regard to immigration period and immigration age. ${ }^{20} 22$ Nevertheless, those analyses were restricted to a small sample.

In the light of the described developments since 1990 , in the countries of the FSU as well as in Germany, we assume that resettlers differ in risk-factor patterns and integration opportunities in Germany depending on the point in time of immigration. Overall, riskfactor patterns, such as tobacco smoking, alcohol consumption and nutrition, may have changed to an unhealthier lifestyle, as a consequence of changes in resettlers' composition. At the same time, deteriorated integration opportunities may have affected the utilisation of healthcare as well as individual well-being and mental health. Both aspects may have had an impact on the mortality of resettlers. Therefore, we first descriptively investigated heterogeneity to describe the migration pattern among resettlers based on immigration periods with respect to sex, age at immigration, country of origin and statutory basis, and second, we investigated differences in mortality according to different immigration periods.

\section{METHODS}

\section{Study design and study population}

The study population consists of three cohort studies $(\mathrm{n}=59390)$, which are located in three different regions of Germany: North Rhine-Westphalia, the Saarland and the city of Augsburg in Bavaria. North Rhine-Westphalia was a quasi-randomly cluster selected sample of resettlers, whereas the Saarland and Augsburg cohorts aimed at complete cohorts of all migrants. Follow-up was done through federal or local registration offices, while health authorities provided death certificates, respectively the causes of death, which were classified according to the International Classification of Diseases 10 (ICD-10). More details on the cohorts and vital status ascertainment are described in Kaucher et al. ${ }^{17}$

\section{Variables}

Person-years (py) were calculated for each sex, calendar year and 5-year age group and the end of follow-up was 31 December 2009. For this study, we further categorised causes of death as follows: all causes, malignant neoplasms (ICD-10: C00-C97), CVD (ICD-10: I00-I99) and external causes (ICD-10: V01-Y84). All deaths from other ICD-10 codes were summarised and categorised as other causes of death. Missing causes of deaths are presented as a separate category. For comparison with the mortality of the general German population, the WHO mortality database was used, which bases on the total population of Germany. ${ }^{23}$

Legislative changes may have been partly a reaction on the observed changes in the composition of resettlers, but they may as well have facilitated the changing composition. Thus, respective calendar years of these legislative changes in Germany were used to categorise immigration periods, which can be seen as a proxy for changes in composition of resettlers: (1) immigrated between 1990 until end of 1992, (2) immigrated between 1993 until end of 1995 and (3) immigrated between 1996 until end of 2005.

\section{Statistical analysis}

In a first step, we descriptively investigated migration pattern by analysing the association between immigration period and the variables sex, age at immigration and country of origin for all cohort members. In addition, information on statutory basis was available from the Saarland cohort. Therefore, we selected a subsample with a random procedure (Saarland cohort, $\mathrm{n}=655$ ).

In a second step, we analysed mortality differences by immigration period to assess the association with resettlers' mortality and migration pattern. We calculated age-standardised mortality rates (ASRs) according to the European standard population, ${ }^{24}$ and standardised mortality ratios (SMRs) in comparison with the general German population, ${ }^{23}$ along with exact $95 \%$ CIs for cause of death categories, stratified by immigration periods and sex. ${ }^{25}$ Therefore, expected numbers of death for SMR calculation relate to resettlers who immigrated in the respective immigration periods. For comparison reasons, we also calculated mean ASRs for the general German population.

Third, we modelled age-specific rates $\mu$, separated by sex, using Poisson regression according to the following model:

$$
\begin{aligned}
\log \left(\mu_{X_{1}, X_{2}, X_{3}}\right)= & \left.\beta_{0}+\beta_{1} X_{1} \text { (immigration period }\right) \\
& +\beta_{2} X_{2}(\text { age grou })+\beta_{3} X_{3}(\text { year })
\end{aligned}
$$


Table 1 Descriptive results, separated by immigration period

\begin{tabular}{|c|c|c|c|c|}
\hline & & \multicolumn{3}{|c|}{ Immigration period } \\
\hline & & $\begin{array}{l}1 \\
(1990-1992)\end{array}$ & $\begin{array}{l}2 \\
(1993-1995)\end{array}$ & $\begin{array}{l}3 \\
(1996+)\end{array}$ \\
\hline \multirow[t]{2}{*}{ Sex in \% } & Men & $48.6 \%$ & $48.0 \%$ & $48.2 \%$ \\
\hline & Women & $51.4 \%$ & $52.0 \%$ & $51.8 \%$ \\
\hline $\begin{array}{l}\text { Mean age at immigration } \\
\text { (median; range) }\end{array}$ & Women & $\begin{array}{l}38.7 \\
(35 ; 0-93)\end{array}$ & $\begin{array}{l}38.6 \\
(36 ; 0-95)\end{array}$ & $\begin{array}{l}37.0 \\
(36 ; 0-98)\end{array}$ \\
\hline \multirow[t]{2}{*}{ Country of origin (n; \%) } & Russian Federation & $\begin{array}{l}223 \\
(1.3 \%)\end{array}$ & $\begin{array}{l}2015 \\
(10.8 \%)\end{array}$ & $\begin{array}{l}7396 \\
(31.6 \%)\end{array}$ \\
\hline & Kazakhstan & $\begin{array}{l}785 \\
(4.5 \%)\end{array}$ & $\begin{array}{l}3902 \\
(20.9 \%)\end{array}$ & $\begin{array}{l}8803 \\
(37.6 \%)\end{array}$ \\
\hline \multicolumn{5}{|c|}{ Subsample Saarland cohort $(n=655)$} \\
\hline \multirow[t]{3}{*}{ Statutory basis in \% } & Unknown & $12.9 \%$ & $4.6 \%$ & $5.0 \%$ \\
\hline & Resettlers & $85.0 \%$ & $80.0 \%$ & $66.2 \%$ \\
\hline & Non-German spouses & $2.2 \%$ & $15.5 \%$ & $28.9 \%$ \\
\hline
\end{tabular}

For the regression, we calculated the person-years for all cross-classifications of age group, calendar year and immigration period. As independent variables, we included immigration period $\mathrm{X}_{1}$ as categorical variable with three categories: (1) 1990-1992 (reference group), (2) 1993-1995 and (3) 1996+, age group $\mathrm{X}_{2}$ (modelled continuously in 5-year age groups, coded as 1 ( $0-5$ years) to $18(85+$ years $)$ ) and year $\mathrm{X}_{3}$ (modelled continuously, coded as 1 to 20 (calendar year-1989)). The offset of the model was the $\log$ of the py in the respective categories. We addressed possible non-linear associations of age and year on the rates using the fractional polynomials procedure. ${ }^{26}$ Using modelled age-specific mortality rates, we calculated ASRs by year and immigration period, standardised to the European standard population. ${ }^{24}$ For comparison, German ASRs were calculated accordingly. ${ }^{23}$ Statistical analyses were performed using SAS V.9.4 and STATA V.14.

\section{RESULTS}

\section{Descriptive results}

Overall, 797264 py were accumulated, and we observed 5572 deaths during the whole observation period. The median follow-up time was 14.2 years. Cause of death was available for $92 \%$ of all deaths. All descriptive results, representing migration patterns by immigration period, are shown in table 1 .

The number of immigrants categorised as 'unspecified FSU countries' decreased considerably to the latest immigration period. However, our data showed higher proportion of resettlers from unspecified FSU countries compared with Germany-wide data since not all cohorts contained the information on the country of origin. Overall, the descriptive results since 1993 and the proportional changes of countries of origin reflect the observed federal trend. Regarding the statutory basis, we found similar migration patterns in the Saarland subsample to the federal trend. While in the first immigration period the majority of immigrating resettlers were ethnic Germans $(85.0 \%)$, the percentage decreased subsequently $(66.2 \%)$, whereas the percentage proportion of non-German spouses increased. On average, resettlers of the latest immigration period were younger compared with resettlers from the first immigration period. No difference in sex composition was observed.

\section{Mortality pattern by immigration period}

Results of all-cause and cause-specific ASR and SMR analyses of resettlers from the FSU, separated by sex and immigration period, are presented in table 2 .

ASRs for all-cause mortality were significantly higher among resettlers from the latest immigration period (ASR (both sexes) 628.1, 95\% CI 595.3 to 660.8) compared with resettlers from the first immigration period (ASR (both sexes) 561.8, 95\% CI 537.2 to 586.4). The same trend can be reported for malignant neoplasms, although not significant. For external mortality, an increase was only found among resettler men who came between 1993 until end of 1995 (ASR 58.2 , $95 \%$ CI 44.1 to 72.4 ) and in the latest immigration period (ASR 53.5, 95\% CI 40.7 to 66.2), compared with resettlers who immigrated before 1993 (ASR 39.7, 95\% CI 29.4 to 50.1). No considerable differences can 


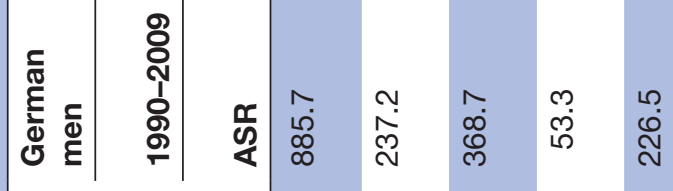

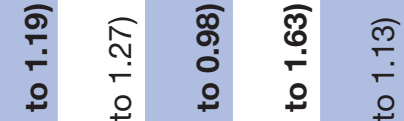

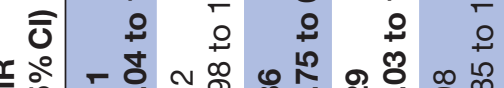

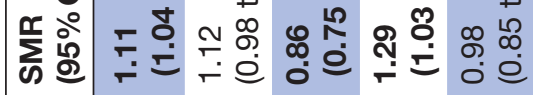

ก $\overline{0}$ क กั

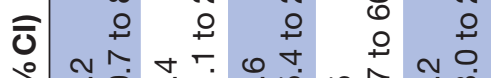

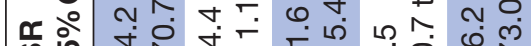

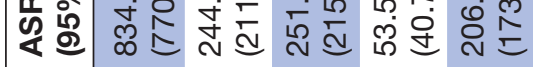
ఫे 4. $\infty E N$ N

○)

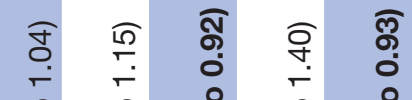
ป

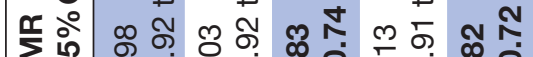
舟

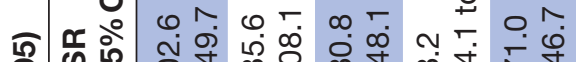

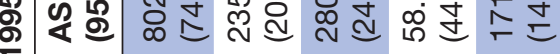

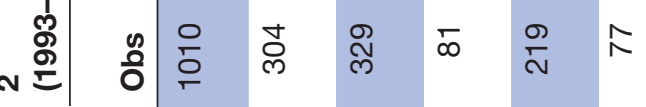

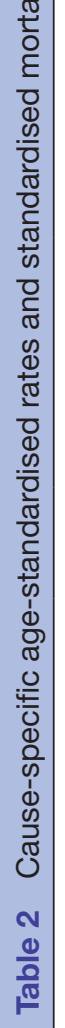

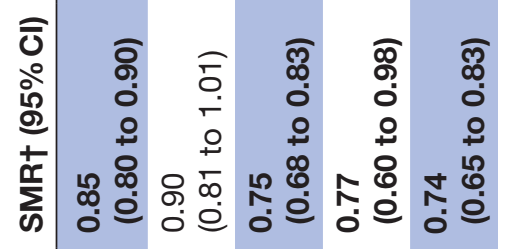

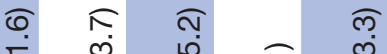

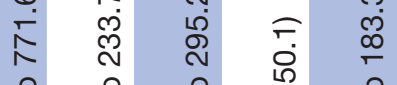

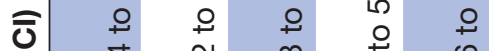
ส্ণ

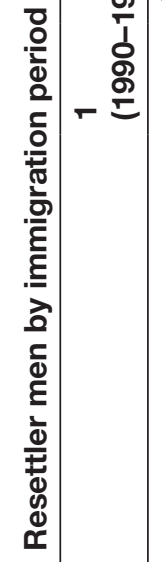

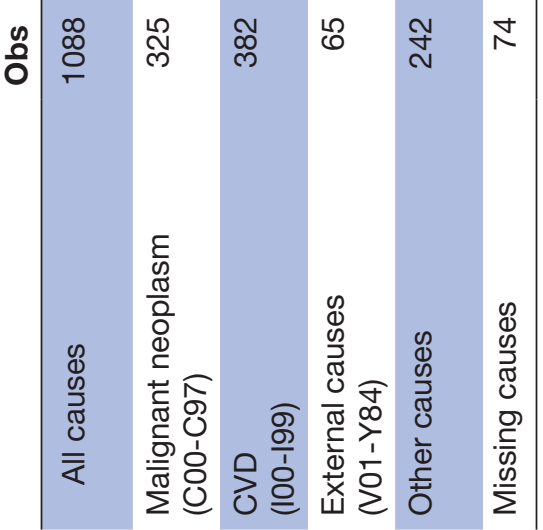

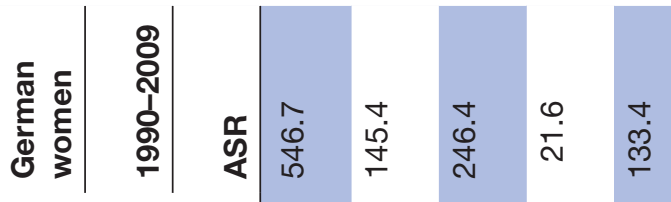

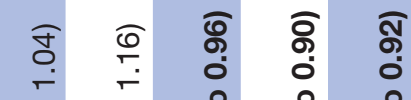

ป

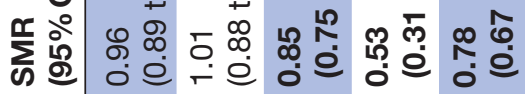

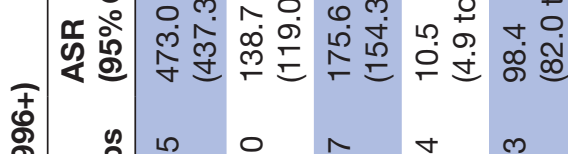

๔

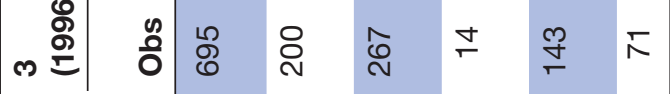

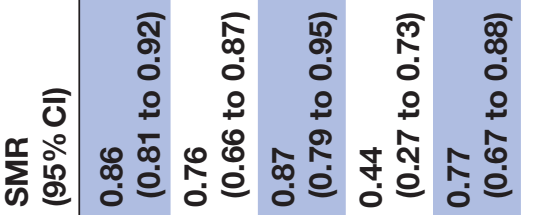

10

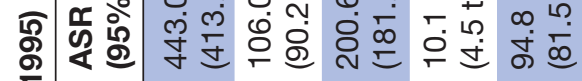

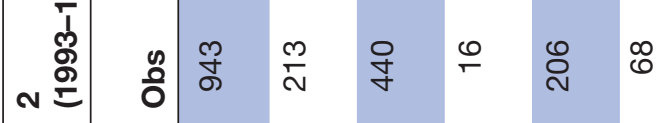

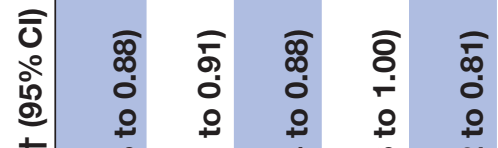

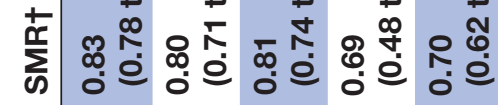

สุ ธุ

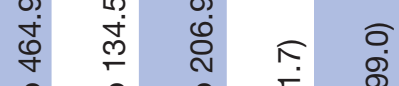

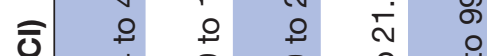

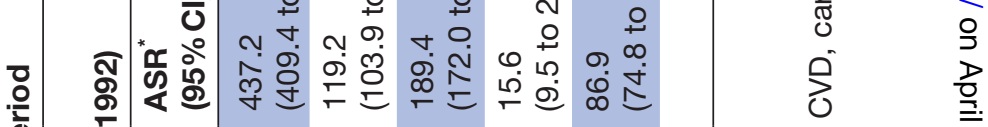

ฮ

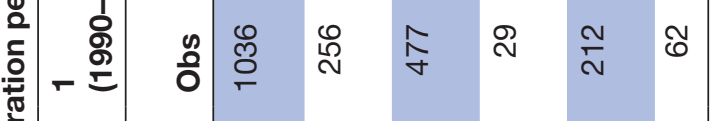

응

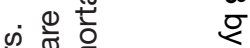

ॠ

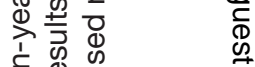

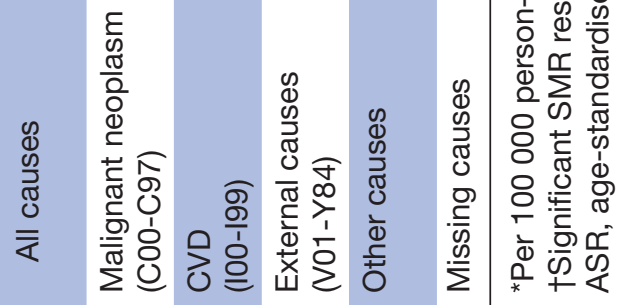


be reported for CVD mortality and for mortality from other causes, in both sexes, respectively.

Results from SMR analysis showed additionally that resettler men from the latest immigration period had a significantly higher all-cause mortality (SMR 1.11, 95\% CI 1.04 to 1.19 ) and external cause mortality (SMR 1.29, $95 \%$ CI 1.03 to 1.63 ) compared with the general German male population.

\section{Poisson regression}

Results from Poisson regression showed significant effects of immigration period, adjusted for age and year. Male resettlers who came within the second immigration period had a significantly higher all-cause mortality compared with resettlers from the first immigration period $(\mathrm{RR}=1.13)$. This effect was even higher for male resettlers who came in 1996 and the years after $(R R=1.23)$. Female resettlers from the second immigration period showed almost the same mortality compared with female resettlers from the first immigration period ( $R R=1.03$, not significant). However, all-cause mortality was significantly higher for female resettlers who came in the last immigration period, compared with resettlers from the first immigration period $(R R=1.13)$. The modelled estimates are presented in the online supplementary material.

Figure 3 presents modelled ASRs, separated by immigration period and sex, from 1990 to 2009 for resettlers and for the general German population. Transformations are shown at the bottom of figure 3. In both sexes, all-cause mortality was lowest among resettlers who came before 1993. Mortality rates among resettlers who came between 1993 and end of 1995 were somewhat higher compared with resettlers who came in the first immigration period, but mortality rates among women were still lower compared with the German population. For male resettlers from the second immigration period, mortality rates crossed the German mortality rates in the mid-2000s. For resettlers who came in 1996 and the years after, mortality rates were highest compared with the other immigration periods. Since 2000, mortality rates of male resettlers were even higher compared with mortality rates of German men. For resettler women who came in 1996 and after, mortality rates remained lower compared with the German rates.

\section{DISCUSSION}

This is a register-based cohort study with mortality as the observed endpoint. We have limited information on covariables that may have an effect on mortality, and therefore this study, due to its size, is able to analyse mortality patterns with respect to immigration period, sex and age. Secondary data indicate covariable patterns that may be linked to these variables; however, interpretation of these covariables towards a relation with mortality is difficult. All the following discussion must be seen in the light of this fact.

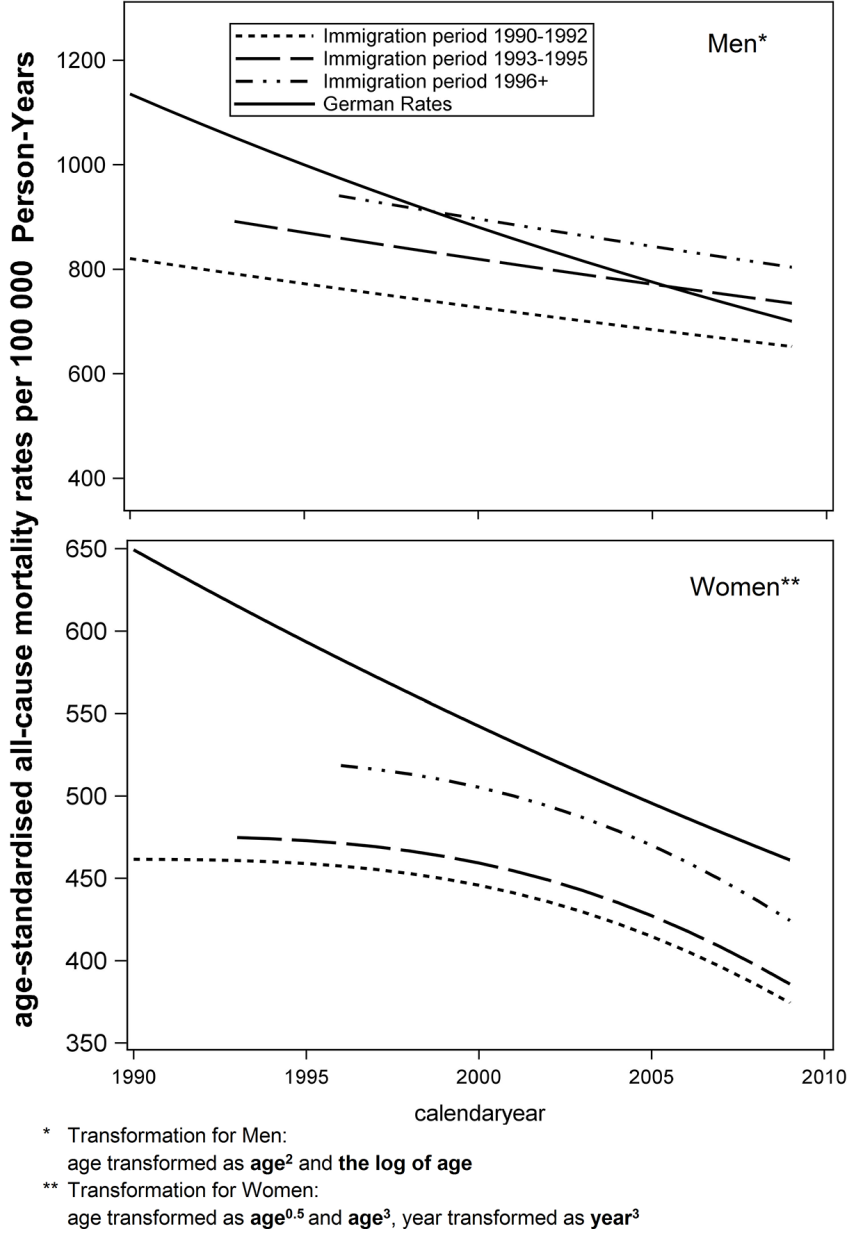

Figure 3 Modelled age-standardised rates for all-cause mortality for resettlers (separated by immigration period and sex) and the German population, using European Standard population, from 1990 to 2009.

We considered three immigration periods, defined by year of relevant legislative changes and found significantly higher all-cause mortality among resettlers from the last immigration period compared with resettlers who immigrated before 1993. Cancer mortality showed the same trend, although not significant. In addition, mortality from external causes among men was found to be increased in resettlers from the last two immigration periods compared with resettlers from the first immigration period (not significant). We put special attention to the comparison of resettler mortality with the mortality of the general German population: All-cause mortality among male resettlers from the third immigration period was found to be higher compared with the mortality of the general German population, whereas mortality among resettler men who immigrated before 1996 was lower. This result, which considers a time component, is of particular interest since so far we only reported overall lower all-cause mortality among resettlers, compared with the general German population.

We believe that the differences in mortality may be linked to the observed changes in the composition of resettlers. As a consequence, resettlers may have had 
different risk-factor patterns, depending on the immigration period. Some authors found that immigration reasons changed over time: while resettlers who came in the beginning immigrated mostly because of ethnical, religious and cultural reasons, this changed to more economic and social reasons already in the early $1990 \mathrm{~s} .{ }^{27}$ Indicators for this are better German language skills in the beginning, which deteriorated over time mainly due to an increasing number of ethnic-mixed couples in the later years, which was observed in several studies. ${ }^{2}{ }^{11} 14$ Descriptive results hint to increasing immigration of ethnic mixed-couples instead of mainly ethnic German couples in the later years, which may have further influenced the risk-factor pattern. Possibly resettlers who immigrated in later years had an unhealthier lifestyle, for example, higher prevalence of smoking and alcohol consumption, compared with resettlers who came in the beginning of the 1990s. Significantly higher mortality among resettlers from the second and third immigration periods, compared with resettlers from the first immigration period, support this assumption. This effect was highest among resettlers, who came 1996 and after in younger ages (<30 years) (RR 1.46, 95\% CI 1.17 to 1.81 ). Poor literacy skills, which are associated with poor health literacy and poor health outcomes, may also explain the differences in resettlers' mortality by immigration period. ${ }^{28} 29$

Differences in mortality may also in part be explained by heterogeneous integration opportunities for resettlers, depending on immigration period. Whereas the acceptance of migrants in the autochthonous population was fairly high in the beginning, it decreased considerably during the 1990s. ${ }^{1130}$ A study found increasing language problems with higher tendencies of withdrawing into resettler peer groups. ${ }^{14}{ }^{31}$ Furthermore, resettlers who immigrated in the beginning of the 1990s had considerably better chances on the labour market compared with resettlers who immigrated in the mid-1990s and later. Since the profession of mostly women and academics was not recognised, many resettlers did not work within their profession and suffered from social relegation. ${ }^{11} 30$ Hence, it can be assumed that the integration of resettlers who came in the beginning was more successful than the integration of resettlers of the later years. ${ }^{2}$ Higher external mortality among resettler men from the latest immigration period, compared with resettler men from the first immigration period, support this assumption. It was shown before that poor integration is associated with mental health problems, as well as with higher risk of suicide and external mortality. ${ }^{20} 32$

A healthy migrant effect among resettlers is unlikely due to several reasons: The restrictions on admission for resettlers were never as rigorous as for other migrant groups. Due to their immediately assigned German citizenship, resettlers have the right of social security and unemployment benefit, as well as the right of permanent residence in Germany. ${ }^{33}$ Furthermore, we investigated that resettlers immigrated mostly with their whole families, and we could observe deaths of older study participants due to severe diseases within a short period after arrival. ${ }^{22} 34$ Nonetheless, to fully rule out a healthy migrant effect, we need to investigate data of resettlers, who remained in the countries of the FSU. However, these data are not yet available. A more detailed discussion about the healthy migrant effect in our study population can be found elsewhere. ${ }^{17}$

The legislative changes were intended to improve the integration process of resettlers, while agglomerations should have been avoided and the communication with the autochthonous population should have been facilitated. Nevertheless, legislative changes were seen controversially. Criticism was addressed towards the inconsistent process of the language test and that the importance of geographical proximity to the social network was neglected. ${ }^{1131}$

We do not assume that immigration period itself had an impact on resettlers' mortality, rather that immigration period reflects different risk-factor patterns and changing integration opportunities for resettlers, thus are influencing mortality. Therefore, immigration period can be seen as a proxy for different risk-factor patterns and integration opportunities.

\section{Strengths and limitations}

It needs to be stated that our study is based on secondary data without any information on risk-factor patterns or on the integration process. Information on educational level and socioeconomic status was not available and could not be accounted for. Additionally, data on statutory basis by immigration period were only available from a subgroup of the Saarland cohort. Nevertheless, our descriptive results reflect the migration pattern of immigrating resettlers from the federal level. ${ }^{12}$ We compared resettler mortality to the mortality of the general German population, which includes migrants and resettlers, which consequently could lead to an underestimation of SMR results. However, in a sensitivity analysis targeting this issue, Deckert found negligible effects of distortion. ${ }^{22}$

We would like to highlight the study design and the long observation period of our study. We were able to investigate mortality for 20 years of follow-up and to distinguish between immigration periods. After arrival, resettlers were assigned to a federal state at random; therefore, we assume that our study population reflects the entire group of resettlers living in Germany and that our results are generalisable to them.

\section{CONCLUSIONS}

Migrants are hardly ever homogeneous groups, which needs to be taken into account when offering healthcare prevention and specific support for better integration. This study demonstrated that this migrant group, which seemed homogeneous at first glance, showed considerable heterogeneity by period of immigration. Further research on resettlers' migration pattern and integration problems, their origin and their impact on health 
may help to substantially improve current and future challenges related to immigration. Health policy should guard the consequences of immigration law alterations with respect to changing compositions of migrant groups and their health status.

Acknowledgements We would like to thank Professor Dr Ernst Lüdemann for his critical reading regarding the historical aspects of this manuscript and his valuable input. We acknowledge the financial support of the Deutsche Forschungsgemeinschaft and Ruprecht-Karls-Universität Heidelberg within the funding programme Open Access Publishing.

Contributors The cohort study was initiated by HB and performed by VW, HB and AD. SK and VW analysed the data. SK drafted the manuscript and all authors contributed to writing and the interpretation of the results.

\section{Competing interests None declared.}

Patient consent Detail has been removed from this case description/these case descriptions to ensure anonymity. The editors and reviewers have seen the detailed information available and are satisfied that the information backs up the case the authors are making.

Ethics approval Ethics Committee of the Medical Faculty, University Hospital Heidelberg.

Provenance and peer review Not commissioned; externally peer reviewed.

Data sharing statement If interested in cooperation, the data set will be provided from the corresponding author.

Open Access This is an Open Access article distributed in accordance with the Creative Commons Attribution Non Commercial (CC BY-NC 4.0) license, which permits others to distribute, remix, adapt, build upon this work non-commercially, and license their derivative works on different terms, provided the original work is properly cited and the use is non-commercial. See: http://creativecommons.org/ licenses/by-nc/4.0/

(c) Article author(s) (or their employer(s) unless otherwise stated in the text of the article) 2017. All rights reserved. No commercial use is permitted unless otherwise expressly granted.

\section{REFERENCES}

1. Eisfeld A. Vom Stolperstein zur Brücke-die Deutschen in Russland. In: Bergner C, Weber M, eds. Aussiedler- und Minderheitenpolitik in Deutschland Bilanz und Perpektiven. München: Oldenbourg Verlag, 2009:79-89.

2. Hensen J. Zur Geschichte der Aussiedler-und Spätaussiedleraufnahme. In: Bergner C, Weber M, eds. Aussiedlerund Minderheitenpolitik in Deutschland Bilanz und Perspektiven. München: Oldenbourg Verlag, 2009.

3. Worbs S, Bund E, Kohls M, et al. (Spät-) Aussiedler in Deutschland. Eine Analyse aktueller Daten und Forschungsergebnisse. Nürnberg: Bundesamt für Migration und Flüchtlinge, 2013.

4. Institut der Deutschen Wirtschaft. Gutachten. Die Integration deutscher Aussiedler - Perspektiven für die Bundesrepublik Deutschland. Köln, 1989.

5. Kiel S. Risiko oder Chance? Identitätsbildung in russlanddeutschen Aussiedlerfamilien. In: Hermann MC, Öhlschläger R, eds. Hier die Russen-dort die Deutschen. Weingarten: Nomos, 2013:p33-48.

6. Bundeszentrale für politische Bildung. (Spät-)Aussiedler. $2012 \mathrm{http}: / /$ www.bpb.de/nachschlagen/zahlen-und-fakten/soziale-situation-indeutschland/61643/aussiedler.

7. Welfens PJJ. Überwindung der Transformationskrise in Rußland. In: Welfens PJJ, Wiegert R, eds. Transformationskrise und neue Wirtschaftsformen in Russland. Heidelberg: Physica-Verlag, 2002:p3-28.

8. Kappeler A. Die Ukraine in der politischen und wirtschaftlichen Transformation (1991-2004). Kappeler A, ed. Kleine Geschichte der Ukraine. München: C.H. Beck, 2014:p255-81.

9. Bundeszentrale für politische Bildung. Nach dem Ende der Sowjetunion, 2014. http://www.bpb.de/izpb/192802/nach-demende-der-sowjetunion? $p=$ all.
10. Worldbank. World Development indicators. 2017 http://databank. worldbank.org/data/reports.aspx?source=world-developmentindicators.

11. Haug S, Sauer L. Zuwanderung und Integration von (Spät-) Aussiedlern: Ermittlung und Bewertung der Auswirkungen des Wohnortzuweisungsgesetzes: Bundesamt für Migration und Flüchtlinge, 2007.

12. Bund E, Kohls M, Worbs S. Zuwanderung und Integration von (Spät-) Aussiedlern in Deutschland. Zeitschrift für Ausländerrecht und Ausländerpolitik 2014;34:349-54.

13. Bundeszentrale für Politische Bildung. (Spät-) Aussiedler in Deutschland, 2013. http://www.bpb.de/apuz/156779/spaetaussiedler-in-deutschland? $p=$ all.

14. Vogelgesang W. Auf dem Weg zur NormalitätIntegrationsfortschritte von jugendlichen Spätaussiedlern. In: Hermann MC, Öhlschläger R, eds. Hier die Russen-dort die Deutschen. Weingarten: Nomos, 2013:p15-32.

15. Becher $\mathrm{H}$, Razum $\mathrm{O}$, Kyobutungi $\mathrm{C}$, et al. Mortalität von Aussiedlern aus der ehemaligen Sowjetunion. Dtsch Arzteb/ 2007;104:1655-61.

16. Deckert $A$, Winkler V, Meisinger $C$, et al. Myocardial infarction incidence and ischemic heart disease mortality: overall and trend results in repatriates, Germany. Eur J Public Health 2014;24:127-33.

17. Kaucher S, Leier V, Deckert A, et al. Time trends of cause-specific mortality among resettlers in Germany, 1990 through 2009. Eur J Epidemiol 2017;32:289-98.

18. Winkler V, Holleczek B, Stegmaier C, et al. Cancer incidence in ethnic German migrants from the Former Soviet Union in comparison to the host population. Cancer Epidemiol 2014;38:22-7.

19. Kuhrs E, Winkler V, Becher H. Risk factors for cardiovascular and cerebrovascular diseases among ethnic Germans from the former Soviet Union: results of a nested case-control study. BMC Public Health 2012;12:1.

20. Deckert A, Winkler V, Meisinger C, et al. Suicide and external mortality pattern in a cohort of migrants from the former Soviet Union to Germany. J Psychiatr Res 2015;63:36-42.

21. Kyobutungi $C$, Ronellenfitsch $\cup$, Razum $O$, et al. Mortality from external causes among ethnic German immigrants from former Soviet Union countries, in Germany. Eur J Public Health 2006; 16:376-82.

22. Deckert A. Myocardial infarction incidence, cardiovascular disease, and external cause mortality pattern among German repatriates: the impact of factual circumstances: University of Heidelberg, 2013.

23. World Health Organization. WHO mortality database. 2015 http:// www.who.int/healthinfo/mortality_data/en/.

24. Pace M, Lanzieri G, Glickman M, et al. Revision of the European standard population: report of Eurostat's task force: Publications Office of the European Union, 2013.

25. Greenland S, Rothman KJ. Introduction to stratified analysis. In: Rothman KJ, Greenland S, Lash TL, eds. Modern epidemiology. 3rd ed. Philadelphia: Lippincott Williams \& Wilkins, 2008:p258-82.

26. Sauerbrei W, Royston P. Building multivariable prognostic and diagnostic models: transformation of the predictors by using fractional polynomials. J R Stat Soc Ser A Stat Soc 1999;162:71-94.

27. Bade KJ, Oltmer J. Aussiedlerzuwanderung und Aussiedlerintegration. Historische Entwicklung und aktuelle Probleme. In: Bade KJ, Oltmer J, eds. Aussiedler: deutsche Einwanderer aus Osteuropa. Osnabrück: Universitätsverlag Rasch, 1999.

28. Schaeffer D, Berens E-M, Vogt D. Health literacy in the German population: results of a representative survey. Deutsches Ärzteblatt International 2017;114:53.

29. DeWalt DA, Berkman ND, Sheridan S, et al. Literacy and health outcomes. J Gen Intern Med 2004;19:1228-39.

30. Thränhardt D. Integration und Partizipation von Einwanderergruppen im lokalen Kontext. In: Bade KJ, Oltmer J, eds. Aussiedler: deutsche Einwanderer aus Osteuropa. Osnabrück: Universitätsverlag Rasch, 1999:p229-46.

31. Struck-Soboleva J. Controversies surrounding language policy and the integration process of Russian Germans in Germany. Language and Intercultural Communication 2006:6:57-75.

32. Kirkcaldy BD, Siefen RG, Wittig U, et al. Health and emigration: subjective evaluation of health status and physical symptoms in Russian-speaking migrants. Stress and Health 2005;21:295-309.

33. Bundesamt für Migration und Flüchtlinge. Migrationsbericht des Bundesamtes für Migration und Flüchtlinge im Auftrag der Bundesregierung, 2016.

34. Winkler V. Specific aspects of the health profile in ethnic german migrants from the former Soviet Union: University of Heidelberg, 2008. 